\title{
Michal Kowalewski
}

Uniwersytet Łódzki

\section{Rozważania nad systemem oceniania w klasach I-III szkoly podstawowej na lamach miesięcznika "życie Szkoły" w latach dziewięćdziesiątych XX wieku}

Przekształcenia społeczno-gospodarcze, polityczne i ekonomiczne, jakie dokonały się w latach dziewięćdziesiątych XX w., wywarły istotny wpływ na reformę systemu edukacyjnego na wszystkich szczeblach szkolnictwa, obejmując swym zakresem również edukację wczesnoszkolną, a więc klasy I-III szkoły podstawowej. Przemiany edukacyjne uwarunkowane były także zmianami podstaw filozoficzno-pedagogicznych, w świetle których budowę systemu edukacyjnego oparto na założeniach psychologii humanistycznej. Zakładała ona swobodny, nieskrępowany i wszechstronny rozwój ucznia w środowisku szkolnym dzięki uaktywnieniu wewnętrznego potencjału dziecka, nieograniczonego zewnętrznymi blokadami wymuszającymi określone zachowania, hamującymi doskonalenie oraz wzrost jego możliwości i zdolności.

$\mathrm{Na}$ etapie kształcenia wczesnoszkolnego jednym z najważniejszych elementów w reformie edukacji okazała się zmiana systemu oceniania szkolnych osiagnięć uczniów. Obok tradycyjnej, obowiązującej dotychczas, formy oceny w postaci cyfrowej pojawiły się systemy zastępujące dotychczasowy stopień układem liter, punktów i symboli. Wśród alternatywnych koncepcji wartościowania edukacyjnej aktywności dziecka w klasach I-III pojawił się również bezstopniowy system oceniania oparty na sporządzanym przez nauczyciela słownym opisie.

W Zarządzeniu Ministra Edukacji Narodowej z 16 lipca 1990 roku w sprawie regulaminu oceniania, klasyfikowania i promowania uczniów po raz pierwszy wprowadzono opisową ocenę osiagnnięć ucznia w pierwszym okresie nauki w klasie I szkoły podstawowej ${ }^{1}$. Jej egzystencja na płaszczyźnie edukacji wczesnoszkolnej została potwierdzona w Zarządzeniu Ministra Edukacji Narodowej z 24 września 1992 roku w sprawie zasad oceniania, klasyfikowania i promowania uczniów w szkołach publicznych dla dzieci i młodzieży oraz

\footnotetext{
${ }^{1}$ Dz.Urz. MENiS, 1990, nr 6, poz. 35.
} 
przeprowadzania egzaminów sprawdzających i klasyfikacyjnych, w którym to w $\S 6$ pkt 4 znalazł się zapis: „uczniowi klasy pierwszej szkoły podstawowej nauczyciel za pierwszy semestr ustala ocenę opisową z zachowania i opisowy stopień ze wszystkich przedmiotów nauczania"”2.

Na płaszczyźnie edukacji wczesnoszkolnej w klasie I szkoły podstawowej dokonało się $\mathrm{w}$ ten sposób istotne, systemowe przeobrażenie, polegające nie tylko na innowacyjnym proceduralnie wartościowaniu działań edukacyjnych uczniów, ale również na zmodyfikowaniu sposobu postrzegania ucznia przez nauczyciela i zmianie metodologii kontroli uczniowskiej wiedzy i poziomu nabytych $\mathrm{w}$ procesie edukacji umiejętności. Wśród pedagogów, nauczycieli, metodyków, a nawet rodziców zrodziło się jednak wiele pytań, powstało wiele kontrowersji i zastrzeżeń wobec nowego systemu oceniania, jakiemu mieli zostać poddani uczniowie. Zastapienie dotychczasowej cyfrowej postaci oceny komentarzem słownym wywołało żywą dyskusję, pełną wątpliwości i rozbieżnych refleksji, dzieląc środowisko pedagogów i metodyków kształcenia na zwolenników i przeciwników alternatywnej koncepcji oceniania.

Wiele opinii, sądów, teoretycznych rozważań i refleksji płynących z praktyki zawodowej znalazło swoje miejsce na łamach „Życia Szkoły”, miesięcznika poświęconego edukacji wczesnoszkolnej, adresowanego do nauczycieli klas I-III, studentów kierunków pedagogicznych, a także rodziców, którego zadaniem jest podnoszenie oraz doskonalenie umiejętności zawodowych pedagogów, poszerzanie wiedzy studentów w zakresie kształcenia zintegrowanego, informowanie o najnowszych koncepcjach pedagogicznych czy publikowanie artykułów z zakresu psychologii, nauczania i wychowania ${ }^{3}$.

Obok prezentacji zalet nowego systemu oceniania zdecydowana większość opublikowanych w latach dziewięćdziesiątych na łamach „Życia Szkoły” artykułów koncentruje się na obnażaniu słabości starego, cyfrowego systemu wartościowania edukacyjnej aktywności uczniów klas początkowych. Poruszone zostają również problemy prawidłowej konstrukcji oceny, właściwego przeprowadzania procesu oceniania uczniów oraz oddziaływania not szkolnych na psychikę ucznia, jego motywację do nauki, zachowania i postawy społeczne.

W opublikowanym w roku 1994 na łamach „Życia Szkoły” artykule Wartościowanie wysitku edukacyjnego dziecka Ryszard Więckowski postulował, by jednym z podstawowych zadań nauczyciela edukacji początkowej było wspieranie aktywności jego podopiecznych ${ }^{4}$. Jak pisał „wymaga to z kolei orientacji nauczyciela odnośnie [do] osiagnięć każdego ucznia czy też ewentualnych trudności napotykanych w procesie indywidualnego rozwoju, następnie zaś sta-

\footnotetext{
${ }^{2}$ Dz.Urz. MENiS, 1992, nr 7, poz. 32.

${ }^{3} \mathrm{http}: / /$ edupress.pl/zycie-szkoly.php.

${ }^{4}$ R. Więckowski, Wartościowanie wysiłku edukacyjnego dziecka, „Życie Szkoły [dalej: ŻSz]" 1994, nr 8, s. 451.
} 
łego diagnozowania osiagnnięć rozwojowych dziecka"5. R. Więckowski zwracał tym samym uwagę na konieczność zindywidualizowanego podejścia nauczyciela do każdego ucznia, monitorowania jego rozwoju, osiąnnięć i postępów, które ten poczynił. Indywidualizacja procesu kształcenia i uwzględnienie różnic rozwojowych między dziećmi stanowią podstawowe warunki prawidłowej, sprawiedliwej oceny ich osiągnięć. Oceny niewyrażającej jedynie stopnia opanowania przewidzianego w programie nauczania materiału, lecz uwzględniającej również szereg istotnych czynników, które proces zdobywania wiedzy i jego końcowy efekt w dużej mierze warunkują.

To pierwsza, wyraźnie wskazana przewaga nowego, opisowego systemu oceniania uczniów w klasie I nad dotychczasowym cyfrowym stopniem. U podstaw genezy i wprowadzenia oceny opisowej do szkół podstawowych leżało przeświadczenie o potrzebie uwzględnienia indywidualności i niepowtarzalności każdego dziecka oraz przekonanie o konieczności podmiotowego, a nie przedmiotowego postrzegania i traktowania ucznia przez nauczyciela. Wartościowanie edukacyjnego wysiłku dziecka miało się odbywać przy wykorzystaniu metod obserwacyjnych, których zewnętrzną formą jest opis określający zarówno uczniowskie sukcesy w postaci zdobytej wiedzy, czy opanowanych umiejętności, uwzględniający wkład pracy i poczynione postępy, jak i wskazujący ewentualne trudności w indywidualnym rozwoju dziecka i wyznaczający kierunki dalszego pedagogicznego działania ${ }^{6}$. Dzięki stosowaniu w codziennej pracy metod, takich jak obserwacje, z założenia wpisanych w system oceniania opisowego, nauczyciel miał doskonałą możliwość dokonania szczegółowej diagnozy poznawczej zarówno zespołu uczniowskiego, jego struktury, norm i relacji w nim panujących, jak i poznania każdego ucznia indywidualnie, zwracając uwage na jego wiedzę, umiejętności, aspiracje, samoocenę, dążenia i zainteresowania, strategie uczenia się, skalę oraz przyczyny ewentualnych edukacyjnych trudności i niepowodzeń. Szeroki zakres uzyskanych dzięki technikom obserwacyjnym informacji umożliwia nauczycielowi nie tylko wielosferyczne i wieloaspektowe zindywidualizowane spojrzenie na ucznia, ale okazuje się również niezwykle przydatny $\mathrm{w}$ procesie planowania pracy dydaktyczno-wychowawczej $\mathrm{z}$ jego podopiecznymi.

W artykule Ocena opisowa w edukacji wczesnoszkolnej - interpretacje rodziców Jolanta Kamińska twierdzi, że: „obserwacja pozwala nie tylko na wykrycie indywidualnych potrzeb dziecka, lecz pomaga w pracy nauczycielowi, który dzięki zebranym informacjom może opracować metody pracy dostosowane do rozwoju dzieci"”. Wyniki obserwacji zjawisk i czynników warunkujących uczniowskie osiagnięcia nie są możliwe do zobrazowania w postaci oceny

${ }^{5}$ Ibidem, s. 451.

${ }^{6}$ Ibidem, s. 451-454.

${ }^{7}$ J. Kamińska, Ocena opisowa $w$ edukacji wczesnoszkolnej - interpretacje rodziców, ŻSz 1999, nr 1, s. 59. 
cyfrowej, noty szkolnej wyrażonej w zamkniętej i przyjętej uprzednio skali, np. od 1 do 6. Stanowią one bowiem indywidualną, nieschematyczną rejestrację szeregu zjawisk, która powinna przyjać formę opisową.

Kolejną wielokrotnie akcentowaną na łamach „Życia Szkoły” przewagę oceniania opisowego nad cyfrowym ujawnia sposób uczniowskiej interpretacji wystawionej przez nauczyciela oceny, a także jej wpływ i oddziaływanie na dziecięcą psychikę, motywację do nauki i postawy społeczne przejawiane w grupie rówieśniczej.

W świetle artykułów poświęconych problematyce oceniania uczniów, publikowanych w latach 90. na łamach miesięcznika „Życie Szkoły” wartościowanie edukacyjnej aktywności na płaszczyźnie wczesnej edukacji odgrywa niezwykle istotną rolę. Szkolne wrażenia i doświadczenia z pierwszego etapu nauczania kształtują bowiem u dziecka świadomość podlegania mechanizmom oceniania zarówno w szkole, jak i w życiu. Systemy oceniania, jakim poddawani są uczniowie klas I-III, warunkują udaną i efektywną adaptację dziecka do nowego środowiska, którym bez wątpienia jest szkoła. W artykule Znaczenie oceny Dorota Celińska-Mitał podkreśla, iż „szkoła w systemie wartości małego dziecka zajmuje ważne miejsce, bowiem moment rozpoczęcia nauki nobilituje społecznie przedszkolaka i stawia go w nowej dla niego sytuacji permanentnego oceniania tego co robi, jak robi i różnych rezultatów jego aktywności”8.

Ocena i proces jej konstruowania oddziałują na psychikę ucznia, kształtując jego nastawienie i motywację do nauki, kreując $\mathrm{w}$ jego świadomości obraz szkoły i nauczyciela wywierają czynny wpływ na dalszy rozwój edukacyjny każdego dziecka. Jak czytamy w artykule Ocenianie jako wartościowanie wysitku edukacyjnego dziecka czy kontrolowanie i testowanie jego osiagnięć szkolnych - mój wybór autorstwa Małgorzaty Zagozdon, „niezbędne jest przy tym stwarzanie dzieciom poczucia bezpieczeństwa, klimatu życzliwości i zaufania między nimi a nauczycielem, sytuacji umożliwiających przeżywanie uczuć radości i zadowolenia $\mathrm{z}$ osiaganych sukcesów, jak też i pokonywanych trudności"”.

Nieprawidłowy system oceniania bądź źle przeprowadzona procedura wartościowania edukacyjnych osiagnięć i postępów mogą przyczyniać się do niepowodzeń szkolnych, wywoływać u dziecka niechęć do nauki oraz implikować powstanie zespołu negatywnych napięć i reakcji nerwowych objawiających się lękiem przed szkołą i obawą przed uczestnictwem w szkolnej społeczności. Stanowisko to podziela Maria Jakowicka, która w artykule Ocena szkolna w przemianach edukacyjnych opublikowanym w „Życiu Szkoły” w 1994 r. podkreśla, że ocena szkolna ,jest takim środkiem, który sięga do najgłębszych,

\footnotetext{
${ }^{8}$ D. Celińska-Mitał, Znaczenie oceny, ŻSz 1993, nr 4, s. 195.

${ }^{9}$ M. Zagozdon, Ocenianie jako wartościowanie wysiłku edukacyjnego dziecka czy kontrolowanie i testowanie jego osiagnięć szkolnych - mój wybór, ŻSz 1994, nr 8, s. 71.
} 
emocjonalnych warstw psychiki, zaburza je lub buduje, a jej odbiór jest zawsze subiektywny" $"$.

Mając na uwadze rozwój wartości społecznych uczniów w klasie I szkoły podstawowej, widać wyraźnie, że niewątpliwą słabością cyfrowego systemu oceniania, akcentowaną w większości artykułów poświęconych problematyce oceniania szkolnego, opublikowanych na łamach ,Życia Szkoły” w latach 90. jest funkcja selekcyjna, jaką stopień spełnia w szkolnej rzeczywistości. Wymierność i możliwość dokonywania zestawień i porównań wystawionych uczniom ocen często staje się źródłem podziału środowiska szkolnego i klasowego na uczniów „lepszych” i ,gorszych”, sami zaś uczniowie postrzegani są nie tyle pod kątem opanowanej wiedzy czy zdobytych umiejętności, ale bardziej przez pryzmat otrzymanego stopnia. Jak czytamy w artykule Kontrowersje wokót oceny szkolnej Elżbiety Misiornej, „Rzeczywistość edukacyjną cechuje kult stopnia. W szkole wszystko się oblicza (prócz tego, co najważniejsze) i wszystkich się wzajemnie porównuje, wywołując zawiść, niezgodę i frustrację tych z ostatnich miejsc w tabelach (oraz lęki i obawę osób zajmujących pierwszą lokatę przed utratą tak znaczącej pozycji). Bo wiszą wszędzie: wykazy ocen poszczególnych uczniów (co powinno być otoczone dyskrecją), ocen każdej klasy i szkoły, ilości wypożyczeń w bibliotece, ilości spóźnień, nieobecności i różnych przedziwnych faktów. I co najważniejsze szkoła tymi liczbami i miejscami w tabelach żyje, szkoła tym się przejmuje"11.

Rozbieżność skali ocen wystawianych przez nauczyciela powoduje podział środowiska szkolnego i klasowego na uczniów mniej i bardziej zdolnych. $\mathrm{R}$. Więckowski $\mathrm{w}$ artykule Założenia a rzeczywistość $w$ systemie oceniania dzieci klas poczatkowych podkreśla: „Przez system stopni wyraźnie przecież dzielimy dzieci na lepsze i gorsze, a musimy pamiętać o tym, że szkoła nie ma prawa poniżać godności człowieka-ucznia"12. Takie podziały implikują wzajemne, antagonistyczne nastawienia obu grup, wywołując jednocześnie zazdrość i negatywnie rozumianą rywalizację o stopnie.

Stanowisko to podziela Mirosław Brzana, który w opublikowanym w $1997 \mathrm{r}$. artykule pt. Rodzice nie pytajcie o stopnie pisze: „Każdy więc, kto woła o częste stawianie dzieciom stopni, to jakby nieświadomie twierdził, iż naczelnymi wartościami są rywalizacja, wrogość, egocentryzm, antyspołeczność, a nie np. umiejętność współdziałania w grupie""13.

Negatywnie pojmowana rywalizacja, chęć zajmowania jak najwyższych lokat powodują że uczniowie swoją aktywność edukacyjną ukierunkowują na chęć zdobywania jak najlepszych ocen, co w swoim artykule podkreśla Małgo-

\footnotetext{
${ }^{10}$ M. Jakowicka, Ocena szkolna w przemianach edukacyjnych, ŻSz 1994, nr 8, s. 454.

${ }^{11}$ E. Misiorna, Kontrowersje wokót oceny szkolnej, ŻSz 1994, nr 8, s. 477.

${ }^{12} \mathrm{R}$. Więckowski, Założenia a rzeczywistość w systemie oceniania dzieci klas poczq̨tkowych, ŻSz 1998, nr 5, s. 259.

${ }^{13}$ M. Brzana, Rodzice, nie pytajcie o stopnie, ŻSz 1997, nr 3, s. 139.
} 
rzata Zagozdon, pisząc: „uczniowie zabiegają nie tyle o to, aby naprawdę stać się mądrzejszymi, lepszymi, ale żeby wypaść lepiej od syna sąsiadki i uzyskać wysoką ocenę szkolną"14, Mirosław Brzana konstatuje zaś: „,nadrzędnym celem w szkole łatwo może stać się szóstka, a nie wiedza i nowe umiejętności”'15.

Wszystko to sprawia, że stopień szkolny staje się pierwszoplanowym, nadrzędnym kryterium, na podstawie którego uczniowie oceniają swoich rówieśników, co w konsekwencji prowadzi do rozbicia więzów i spójności grupowej oraz utrudnia adaptację z uwagi na lęk przed otrzymaniem złej oceny. Ryszard Więckowski jest ponadto zdania, że „stopnie stają się narzędziem zastraszania uczniów. Problem ten dodatkowo komplikuje efekt Nimbu. Jest to powszechna skłonność wychowawców do sympatii i antypatii. Uczeń postrzegany przez nauczyciela jako sympatyczny jest przez niego traktowany jako bardziej zdolny i odwrotnie" 16 . Stereotypowe postrzeganie uczniów przez nauczyciela, poprzez pryzmat wystawionych stopni, czyni każdą procedurę oceniania wątpliwą w aspekcie jej rzetelności i sprawiedliwości. Prawidłowo sporządzona i wystawiona przez nauczyciela ocena powinna odzwierciedlać aktualny stan wiedzy ucznia $\mathrm{z}$ uwzględnieniem jego wysiłku włożonego $\mathrm{w}$ proces zdobywania wiedzy oraz postępów, jakie na tej drodze poczynił, a w ocenie cyfrowej „bardzo trudno uwzględnić te wszystkie czynniki" ${ }^{17}$.

W artykule pt. Ocenianie jako wartościowanie wysiłku edukacyjnego dziec$k a$ czy kontrolowanie i testowanie jego osiagnięć szkolnych - mój wybór Małgorzaty Zagozdon czytamy: „Od momentu kiedy wprowadziłam opisową formę oceniania wysiłku uczniów przestały mną targać uczucia niepewności i obawy, czy stawiając dziecku 2, 1, 3, nie krzywdzę go. Nauczyciel jest przecież tylko niedoskonałym człowiekiem, który również popełnia błędy. Zawsze starałam się być obiektywna, ale nie miałam często pewności, czy nie skrzywdziłam dziecka zbyt niską oceną. Ocena opisowa eliminuje takie pomyłki”"18.

Jak wynika z toczącego się na łamach „Życia Szkoły” w latach 90. dyskursu poświęconego ocenianiu uczniów w edukacji wczesnoszkolnej, tradycyjny, cyfrowy stopień nauczyciele często wykorzystują jako środek dyscypliny i zaprowadzania ładu w klasie, traktując go przy tym jako najlepszy środek motywacyjny. M. Brzana twierdzi: „Wielu nauczycieli (o ile nie większość) nie wyobraża sobie, aby można było bez stosowania stopni skłonić ucznia do jakiejkolwiek aktywności”19 , zaś R. Więckowski wyraźnie podkreśla: „nauczyciel $\mathrm{z}$ racji zawodowych powinności za sprawą regulaminu klasyfikowania i promowania, ma okazję do oceniania drugiego człowieka poprzez rozdawanie

\footnotetext{
${ }^{14}$ M. Zagozdon, Ocenianie jako wartościowanie..., s. 71.

${ }^{15}$ M. Brzana, Rodzice, nie pytajcie..., s. 139.

${ }^{16}$ R. Więckowski, Założenia a rzeczywistość..., s. 262.

${ }^{17}$ P. Kowolik, O ocenie i ocenianiu uczniów, ŻSz 1994, nr 8, s. 462.

${ }^{18}$ M. Zagozdon, Ocenianie jako wartościowanie..., s. 74.

${ }^{19}$ M. Brzana, Rodzice, nie pytajcie..., s. 139.
} 
na lekcji nagród i kar w postaci stopni" ${ }^{20}$. Wykorzystywanie stopnia jako kary lub nagrody w rzeczywistości nie spełnia jednak funkcji motywacyjnej, wręcz przeciwnie, uczniowie, którzy otrzymują niskie stopnie, mają obniżone poczucie własnej wartości, przestają wierzyć w siebie, nisko oceniają swoje możliwości i przejawiają aspołeczne postawy wobec kolegów i koleżanek, gdyż: „Kiedy dostało się trójkę lub czwórkę, nawet piątkę, to łatwo zaczać zazdrościć i stracić sympatię do szóstkowicza, a na dodatek - stracić wiarę w sens uczenia się"21.

$\mathrm{W}$ przeciwieństwie do cyfrowego stopnia ocena opisowa motywuje dziecko do nauki, stymuluje jego dalszą aktywność edukacyjną i jak podkreśla Małgorzata Zagozdon: „zawsze dziecko znaleźć w niej może taki element swojej działalności-aktywności, który uzyskał u nauczyciela aprobatę. Każdy za coś jest pochwalony, bo przecież w każdym potrafimy znaleźć pozytywne cechy i każdego za coś pochwalić"22.

Kolejną niewątpliwą słabością cyfrowego systemu oceniania, akcentowaną na łamach „Życia Szkoły” przez autorów artykułów poświęconych tej problematyce, oprócz braku motywacji, jest również niski stopień informacji zwrotnej na temat swoich osiagnięć, jaki charakteryzuje uczniów, którym nauczyciele wystawili ocenę w formie cyfrowej. W artykule Rodzice nie pytajcie o stopnie Mirosław Brzana zaznacza: „Siedmio- czy ośmiolatkowi bardzo trudno jest wythumaczyć informacyjne znaczenie oceny. Dla niego szóstki będą cennymi zdobyczami, skarbami, które można kolekcjonować i którymi można się pysznić przed kolegami, a stopień niższy zawsze będzie odebrany jako porażka, jeśli nie klęska"23. Ocena w postaci cyfrowej nie wyjaśnia uczniowi, na czym polegały jego błędy, nie wskazuje obszarów i sposobów doskonalenia wiedzy i umiejętności, a przede wszystkim nie uwzględnia jego wysiłku i poczynionych postępów oraz nie podkreśla wyraźnie tego, co zrobił dobrze, motywując go tym samym do dalszej pracy i dalszej aktywności. Jak twierdzi Jolanta Kamińska: „Ocena $\mathrm{w}$ formie cyfry jest oceną za efekt końcowy wykonanej pracy, nie uwzględniającą włożonego weń wysiłku. W momencie, kiedy w edukacji dochodzi do głosu indywidualizacja wymagań, powinniśmy zrezygnować ze stosowanego do tej pory sposobu oceniania i wykorzystać możliwość, jaką daje nam opis osiagnięć edukacyjnych na podstawie obserwacji” ${ }^{24}$. Zdaniem J. Kamińskiej alternatywny względem stopnia opisowy system oceniania „umożliwia wyeksponowanie wszystkiego, co dziecko już osiągnęło i daje możliwość podpowiedzenia dziecku i rodzicom, lub opiekunom, co jeszcze należy zrobić, aby osiaggnąć pełen sukces. Daje też możliwość informowania rodziców o osiągnięciach dziecka, przy jednoczesnym zwróceniu uwagi na występujące proble-

\footnotetext{
${ }^{20}$ R. Więckowski, Założenia a rzeczywistość..., s. 259.

${ }^{21}$ M. Brzana, Rodzice, nie pytajcie..., s. 140.

${ }^{22}$ M. Zagozdon, Ocenianie jako wartościowanie..., s. 74.

${ }^{23}$ M. Brzana, Rodzice, nie pytajcie..., s. 139.

${ }^{24}$ J. Kamińska, Ocena opisowa w edukacji..., s. 24.
} 
my, a także wyeksponowania zainteresowań, co daje z kolei możliwość pielęgnowania aktywności w dalszym kierunku. Mamy możliwość pełnego wspierania aktywności edukacyjnej dziecka, rozwoju jego zdolności i osobowości, zwracając uwagę na jego osiagnięcia, regulując jego stany emocjonalne, prowadząc do tego, że osiagnie ono zdolność samodzielnego pokonywania stresów, rozwijając jego zainteresowania itp." 25

W przeciwieństwie do oceny cyfrowej bezstopniowy system oceniania, oparty na słownym opisie, spełnia zatem funkcję diagnostyczną (przedstawia przejawy rozwoju dziecka ze szczególnym uwzględnieniem jego cech dodatnich), prognostyczną (uwzględnia dziecięce zaangażowanie i aktywność poznawcza) oraz informacyjno-wychowawczą (zapewnia poczucie bezpieczeństwa, pełniejszą informację o osiągnięciach i indywidualizacji pracy) ${ }^{26}$.

Uwzględnienie wysiłku i postępów poczynionych przez ucznia, jego zaangażowania: „zmniejsza uczucie wstydu i lęku, podnosi wiarę we własne siły i działając motywacyjnie wyzwala ukryty w uczniu potencjał ${ }^{27}$. Jak twierdzi Małgorzata Zagozdon - dzięki ocenie opisowej: „dziecko i jego rodzice otrzymują wskazówki, jak przezwyciężać trudności, dostają informację, co dziecko potrafi robić bardzo dobrze, a nad czym musi jeszcze popracować"28.

W świetle zdecydowanej większości artykułów opublikowanych w latach dziewięćdziesiątych na łamach „Życia Szkoły” widać wyraźnie, że zastapienie w klasie I szkoły podstawowej tradycyjnego stopnia oceną opisową zdobyło uznanie ich autorów. W swoich rozważaniach podkreślają oni, iż dzięki temu dokonała się zmiana charakteru oceniania wczesnoszkolnego z selekcyjnorestrykcyjnego na informacyjno-diagnostyczny. Miało to sprzyjać przyjaznej atmosferze $\mathrm{w}$ grupie rówieśniczej, wpływać na pozytywne postrzeganie przez ucznia zarówno szkoły, jak i nauczyciela. Dzięki ocenie opisowej uczniowie mieli szansę stać się bardziej twórczy i otwarci, ich rozwój nie był bowiem hamowany stresem przed otrzymaniem złej oceny za nieprawidłową względem oczekiwań nauczyciela postawę. Wyeliminowane zostało zjawisko wykorzystywania przez nauczyciela stopnia jako kary i środka służącego zaprowadzeniu i utrzymaniu klasowej czy też szkolnej dyscypliny. Kreowany przez ocenę opisową klimat sprzyjał zaangażowaniu i motywacji do dalszej nauki, aktywność edukacyjna dziecka koncentrowała się wokół chęci poszukiwania nowej wiedzy i nowych doświadczeń, które powinny być nadrzędne względem stopnia, punktów czy znaczków - głównych determinantów uczniowskiego działania $\mathrm{w}$ tradycyjnych modelach oceniania.

W części artykułów opublikowanych w latach 90. na łamach „Życia Szkoły" zasadność zastapienia oceny cyfrowej sporządzanym przez nauczyciela

\footnotetext{
${ }^{25}$ Ibidem, s. 24.

${ }^{26} \mathrm{R}$. Więckowski, Założenia a rzeczywistość..., s. 264.

${ }^{27}$ R. Sawala, E. Zierhoffer, Ocenianie - problem otwarty, ŻSz 1994, nr 8, s. 465.

${ }^{28}$ M. Zagozdon, Ocenianie jako wartościowanie..., s. 74.
} 
opisem potwierdzona została przez ich autorów za pomocą procedury badawczej. Badania te objęły swym zakresem nie tylko środowisko szkolne, a więc uczniów i nauczycieli, uwzględniono w nich również opinie rodziców, których dzieci na co dzień podlegają ocenianiu w szkołach. J. Kamińska w artykule Ocena opisowa w edukacji wczesnoszkolnej - interpretacje rodziców, dokonując analizy wyników przeprowadzonej z rodzicami ankiety, zauważa, iż tradycyjny stopień szkolny nie spełnia ich oczekiwań, nie informuje bowiem rodziców o osiaggnięciach ich dzieci, nie daje również żadnych wskazówek do dalszej pracy, nie wskazuje sfer edukacji i rozwoju, na które rodzice powinni zwrócić szczególną uwagę ${ }^{29}$. W konsekwencji, ponad 92\% ankietowanych rodziców twierdzi, iż obecność oceny opisowej w klasie I szkoły podstawowej jest w pełni uzasadniona, a część z nich jest zdania, że powinna ona objąć swym zakresem także klasę II i III, a więc obowiązywać na całej płaszczyźnie edukacji wczesnoszkolnej ${ }^{30}$.

Piotr Kowolik w artykule $O$ ocenie $i$ ocenianiu uczniów, prezentując wyniki procedury badawczej przeprowadzonej z udziałem nauczycieli szkół podstawowych, podkreśla, że $92 \%$ ankietowanych pedagogów potwierdziło większy obiektywizm, skuteczność i sprawiedliwość oceny opisowej i wspólnie ze zdecydowaną większością współuczestniczących w badaniu rodziców (72\%) preferuje tę postać oceny, nie tylko w klasie $\mathrm{I}^{31}$.

Tylko w jednym artykule, z opublikowanych na łamach „Życia Szkoły” w ostatnim dziesięcioleciu XX w., dostrzec można krytyczne spojrzenie na nowy system oceniania szkolnych osiagnięć uczniów w klasie I szkoły podstawowej. Należy jednak zauważyć, iż rozważania i refleksje jego autorki - Doroty Śliwińskiej - nie są na tyle wymierzone w założenia bezstopniowego systemu oceniania, ile są wyrazem popartej procedurą badawczą analizy działań nauczycieli oceniających uczniów w sposób opisowy. D. Śliwińska zauważa, iż wielu $z$ nich nie przejawia zindywidualizowanego podejścia do swoich podopiecznych. Analizując oceny opisowe pochodzące z różnych szkół podstawowych, autorka stwierdza: „tylko przy dwóch ocenach można mówić o zindywidualizowanym podejściu do dziecka; reszta ocen to sformalizowane, ogólne informacje, formułowane na podstawie schematu jednakowego dla wszystkich uczniów; różnią się właściwie tylko słowami charakteryzującymi poziom opanowania pewnych wiadomości, umiejętności np. w stopniu dobrym, niewystarczającym, itp." ${ }^{32}$ Podkreślając ogólnikowość, brak szczegółów dotyczących przebiegu nauki dziecka, dostrzegając schematyzm i szablonowość w konstrukcji ocen opisowych, D. Śliwińska, twierdzi, że tak skonstruowane oceny opisowe „nie

\footnotetext{
${ }^{29}$ J. Kamińska, Ocena opisowa w edukacji.., s. 57.

${ }^{30}$ Ibidem, s. 57.

${ }^{31}$ P. Kowolik, O ocenie i ocenianiu..., s. 464.

${ }^{32}$ D. Śliwińska, W sprawie oceny opisowej, ŻSz 1998, nr 4, s. 207.
} 
spełniają w praktyce wyznaczonych im funkcji. A źle, nierzetelnie i niestarannie opracowana ocena dziecka może mu wyrządzić więcej szkody niż dawne oceny wyrażone stopniem"33. W artykule $W$ sprawie oceny opisowej D. Śliwińska formułuje swoisty apel do nauczycieli, aby nie zaprzepaścili możliwości, jakie stwarza i jakie wniosło ocenianie opisowe do szkół podstawowych i „by oceny cyfrowej nie zastapić opisowa, która $\mathrm{w}$ dalszym ciąu stanowiłaby jedynie zapisaną schematycznym ciągiem wyrazów wycenę za postępy dydaktyczne ucznia, tak jak to miało miejsce w dotychczasowej praktyce szkolnej”34.

Nowe możliwości przeprowadzania oceniania w placówkach szkolnych stworzyło Zarządzenie Ministra Edukacji Narodowej z 30 czerwca 1993 roku w sprawie zasad i warunków prowadzenia działalności innowacyjnej przez szkoły i placówki publiczne, w świetle którego właściwy kurator oświaty uzyskał możliwość wyrażenia zgody na wprowadzenie wewnątrzszkolnego systemu oceniania, odmiennego od ogólnie obowiązujących zasad ${ }^{35}$.

Na łamach „Życia Szkoły” w latach 90. w ramach otwartej, poświęconej ocenianiu najmłodszych uczniów dyskusji pojawiły się artykuły, których autorzy - nauczyciele-praktycy - prezentują własne, często autorskie i innowacyjne techniki i metody na podstawie których przeprowadzają procedurę oceniania uczniów w swojej codziennej pracy zawodowej.

Róża Sawala i Ewa Zierhoffer w artykule Ocenianie - problem otwarty proponują wdrożenie do systemu nagradzania aktywności uczniów punktacji (za każdy przejaw aktywności w wybranych dziedzinach edukacyjnych), drzewek wiedzy (na których umieszczane są owoce symbolizujące nowo zdobyte umiejętności), puzzlli (za przejawy aktywnej i twórczej pracy w trakcie zajęć lekcyjnych dziecko otrzymuje elementy układanki, z których z czasem powstaje cały obrazek), a dla tych najzdolniejszych przewidują nawet możliwość chwilowego zastąpienia nauczyciela i samodzielnego poprowadzenia własnych zajęć dla swoich kolegów i koleżanek $\mathrm{z}$ grupy rówieśniczej ${ }^{36}$. Autorki w trosce o jednakowe szanse osiągnięcia sukcesu przez wszystkie dzieci proponują również opracowany przez nie system samooceny uczniów, dokonywany na podstawie tzw. wykresu indywidualnych osiągnięć, uwzględniającego nie tylko opanowaną wiedzę z zakresu poszczególnych przedmiotów nauczania, ale również zaangażowanie i poczynione postępy ${ }^{37}$.

Anna Dudzińska i Gabriela Gajewska proponują opracowany specjalnie na potrzeby oceniania w klasach pierwszych szkół podstawowych kwestionariusz oceny opisowej, w którym zwracają uwagę na konieczność uwzględnienia nie tylko wiedzy i dziecięcych predyspozycji do nauki, ale również wad rozwojo-

\footnotetext{
${ }^{33}$ Ibidem, s. 209.

${ }^{34}$ Ibidem.

${ }^{35}$ R. Sawala, E. Zierhoffer, Ocenianie - problem otwarty..., s. 465.

${ }^{36}$ Ibidem, s. 465.

${ }^{37}$ Ibidem, s. 467-468.
} 
wych, co umożliwi szybkie ich wykrycie i kierowanie dzieci do odpowiednich specjalistów i poradni ${ }^{38}$.

Zofia Cenek w artykule Elementy oceny opisowej w klasie I zachęca nauczycieli do konstruowania rozszerzonej oceny opisowej, uwzględniającej $\mathrm{m}$. in. funkcje poznawcze, zainteresowania, rozwój emocjonalny, rozwój woli, stosunek do obowiązków szkolnych, postawy społeczne, trudności sprawiane przez ucznia i ich przyczyny ${ }^{39}$.

Magdalena Roszkowska-Przetacznik i Dorota Słowik przyjmując założenie, że „dzieci kierując się wewnętrzną motywacją pracują chętnie i mocno angażują się w wykonywanie powierzonych zadań” 40 oraz „dostrzeganie włożonego wysiłku i wspieranie dzieci w kolejnych działaniach podnosi ich wiarę we własne siły"41, opierając się na swoich zawodowych doświadczeniach, wynikających $\mathrm{z}$ prowadzenia klasy integracyjnej $\mathrm{w}$ szkole podstawowej, opracowały nową formę świadectwa szkolnego, które wnikliwie ocenia poszczególne sprawności z zakresu edukacji, a także podwójną ocenę, wskazującą stopień opanowania materiału oraz wysiłek włożony w pracę ${ }^{42}$.

W artykule Ocena opisowa a rozwój dziecka Stanisława Piecha i Ireny Krupy opublikowanym na łamach „Życia Szkoły” w 1994 r. znajdziemy gotowe wzorce i przykłady listów motywacyjnych adresowanych do uczniów, ocen opisowych formułowanych przez nauczycieli oraz szereg elementów i wskazówek pomocnych do ich konstrukcji ${ }^{43}$.

Problem modeli oceniania, możliwych do zastosowania na płaszczyźnie edukacji początkowej, poruszył również Bogusław Śliwerski w artykule $O$ różnorodności oceniania $w$ edukacji wczesnoszkolnej, dokonując porównawczego zestawienia kilku odmiennych modeli oceniania, funkcjonujących w szkolnej rzeczywistości klas I-III szkoły podstawowej. Obok modelu tradycyjno-legalistycznego (w którym stopnie wystawiane są uczniom w postaci not szkolnych), modeli oceny punktowej i literowej (w których nocie szkolnej nadaje się postać określonej liczby punktów czy też przypisuje właściwą dla przyjętej uprzednio skali literę alfabetu) pojawia się również model alternatywny, w którym nie uzyskuje się stopni, lecz skonstruowaną na podstawie przeprowadzonej przez nauczyciela obserwacji ocenę opisową, stanowiąca podsumowanie dotychczasowych wyników $\mathrm{w}$ nauce, uzyskanych osiagnnięć i poczynionych postępów

${ }^{38}$ A. Dudzińska, G. Gajewska, Elementy oceny opisowej $w$ klasie I, ŻSz 1994, nr 8, s. $486-487$.

${ }^{39}$ Z. Cenek, Elementy oceny opisowej w klasie I, ŻSz 1994, nr 8, s. 489-493.

${ }^{40}$ M. Roszkowska-Przetacznik, D. Słowik, Ocena inaczej - z doświadczeń klasy integracyjnej, ŻSz 1994, nr 8, s. 494.

${ }^{41}$ Ibidem, s. 494.

${ }^{42}$ Ibidem, s. 494-500.

${ }^{43}$ S. Piech, I. Krupa, Ocena opisowa a rozwój dziecka, ŻSz 1994, nr 8, s. 502-504. 
(w dwóch wariantach - jeden bez stopni, ale klasyfikacyjny i drugi, pozbawiony stopni, bez promocji) ${ }^{44}$.

Swoje refleksje na temat modeli oceniania i ich modyfikacji dokonywanych często przez nauczycieli zaprezentowała również Elżbieta Misiorna w artykule Kontrowersje wokół oceny szkolnej, podkreślając przy tym, że „W wielu sytuacjach po prostu zamieniono tradycyjną cyfrę na pewne symbole (uśmiechnięte buzie, kwiatki, znaczki, kolorowe kółka, misie, stempelki, żetony itp.)" ${ }^{\text {"45 }}$.

Na mocy Ustawy o zmianie ustawy o systemie oświaty z 25 lipca $1998 \mathrm{r}$. oraz wydanego przez Ministra Edukacji Narodowej 19 kwietnia 1999 r. Rozporządzenia w sprawie zasad oceniania, klasyfikowania i promowania uczniów, przeprowadzania egzaminów i sprawdzianów w szkołach publicznych ujednolicono system oceniania zewnętrznego, który w odniesieniu do nauczania zintegrowanego przyjął formę oceny opisowej ${ }^{46}$.

W artykule Ocena opisowa... Bożena Stendera twierdzi, że dzięki wprowadzeniu takiej formy ocenianie na płaszczyźnie edukacji wczesnoszkolnej, a więc w klasach I-III szkoły podstawowej, zostało zorientowane na: „Kształtowanie indywidualnej drogi rozwoju dziecka, sprzyjanie jego rozwojowi, eliminowanie napięć, rywalizacji, informowanie ucznia o jakości jego osiagnięć w porównaniu z celami kształcenia, przy jednoczesnym uwzględnieniu postępów i wysiłku włożonego przez dziecko w proces edukacyjny" ${ }^{, 47}$.

W opublikowanym na łamach „Życia Szkoły” w roku 2000 artykule Propozycja oceny opisowej Katarzyna Witkowska prezentuje opracowany przez siebie, oparty na programie nauczania Zintegrowana edukacja wczesnoszkolna, kwestionariusz, jako narzędzie przydatne dla procesów obserwacji i konstrukcji oceny opisowej, obowiązującej już na płaszczyźnie całej edukacji wczesnoszkolnej ${ }^{48}$.

Dyskusja i rozważania nad systemem oceniania w klasach I-III pozostaja wciąż aktualne i otwarte, a „Życie Szkoły” dalej, aż po dzień dzisiejszy, pozostaje otwartym forum wymiany myśli, opinii i poglądów związanych z problemem wartościowania edukacyjnej aktywności dziecka na płaszczyźnie edukacji wczesnoszkolnej. Pojawiają się wciąż nowe pomysły, spostrzeżenia, publikowane są wyniki $z$ przeprowadzonych procedur badawczych i często autorskie rozwiązania praktyczne, będące wynikiem innowacji wprowadzonych do świata

${ }^{44}$ B. Śliwerski, O różnorodności oceniania w edukacji wczesnoszkolnej, ŻSz 1994, nr 8, s. $469-476$.

${ }^{45}$ E. Misiorna, Kontrowersje wokót oceny szkolnej, ŻSz 1994, nr 8, s. 477.

${ }^{46}$ Ustawa z dnia 25 lipca 1998 r. o zmianie ustawy o systemie oświaty, Dz.U. 1998, nr 117, poz. 759 oraz Rozporzadzenie Ministra Edukacji Narodowej z dnia 19 kwietnia 1999 r. w sprawie zasad oceniania, klasyfikowania $i$ promowania uczniów i sluchaczy oraz przeprowadzania egzaminów i sprawdzianów w szkołach publicznych, Dz.U. 1999, nr 41, poz. 413.

${ }^{47}$ B. Stendera, Ocena opisowa, ŻSz 2000, nr 10, s. 643.

${ }^{48}$ K. Witkowska, Propozycja oceny opisowej, ŻSz 2000, nr, s. 47-51. 
ocen szkolnych przez nauczycieli szkół podstawowych w ramach codziennej praktyki zawodowej.

Najważniejsze, aby rozważaniom nad systemem oceniania w klasach I-III przyświecał jeden cel - dobro dziecka i jego wszechstronnego rozwoju, tak aby, jak postuluje w swym artykule Mirosław Brzana, odwieczne pytanie „Jaki stopień dzisiaj dostałeś?" "49 skierowane do ucznia (dziecka) zamienić na pytanie „Czego się dziś nauczyłeś, co nowego poznałeś, co cię zaciekawiło" ${ }^{\text {, }}$.

\footnotetext{
${ }^{49}$ M. Brzana, Rodzice nie pytajcie..., s. 141.

${ }^{50}$ Ibidem, s. 141.
} 